\title{
FASIITIS NEKROTIKAN TIPE II
}

\author{
Oktavia R. L. Sondakh \\ Damayanti Tangkidi \\ Herry E. J. Pandaleke
}

\author{
Departemen Ilmu Kesehatan Kulit dan Kelamin \\ Fakultas Kedokteran Universitas Sam Ratulangi Manado \\ Email: reymondsondakh@yahoo.com
}

\begin{abstract}
Necrotizing fasciitis, often called flesh eating bacteria, is a progressive necrosis in subcutaneous fat and fascia. Type II necrotizing fasciitis caused by Acinetobacter baumannii is rarely found. Predisposing factors of necrotizing fasciitis include elderly, immunocompromised condition, chronic diseases, alcoholism, and trauma. We reported a case of a 68-year-old male complained of dark red swelling accompanied by pain in the left thigh. On examination of the left femoral region, there was a diffuse macula, plaque sized, erythematous to black colored, with erosion, excoriation, and necrotic tissue. Hematological examination showed the LRINEC score of 6 . The pus culture result was Acinetobacter baumannii. The patient was given systemic antibiotics and debriedement was performed. The lesion did not extend anymore and the patient's general condition became better. Post debridement, the ulcer was treated with hydrogel wound dressings containing honey. After 60 days, the ulcer healed with a hypertrophic scar. Conclusion: This case was diagnosed as type II necrotizing fasciitis caused by Acinetobacter baumannii based on anamnesis, physical examination, hematological examination, and pus culture which were typical for this diagnosis.
\end{abstract}

Keywords: type II necrotizing fasciitis, LRINEC score

\begin{abstract}
Abstrak: Fasiitis nekrotikan (FN) atau sering disebut "flesh eating bacteria" adalah nekrosis progresif di lemak sub kutan dan fascia. Fasciitis nekrotikan tipe II yang disebabkan oleh Acinetobacter baumanii jarang ditemukan. Faktor predisposisi FN antara lain usia lanjut, imunokompromais, penyakit kronik, alkoholisme, dan trauma. Kami melaporkan seorang lakilaki berusia 68 tahun dengan bengkak merah kehitaman yang disertai nyeri di paha kiri. Pada pemeriksaan regio femoralis sinistra terdapat makula difus, ukuran plakat, eritem sampai kehitaman, disertai erosi, eskoriasi, dan jaringan nekrotik. Pemeriksaan hematologik menunjukkan skor LRINEC 6. Hasil kultur pus Acinetobacter baumanii. Pasien mendapatkan antibiotik sistemik dan dilakukan debrideman. Lesi tidak meluas dan keadaan umum pasien baik setelah penanganan dengan antibiotik dan debrideman. Ulkus paska debrideman dirawat dengan balutan luka hidrogel mengandung madu. Ulkus sembuh dengan meninggalkan skar hipertrofik setelah 60 hari. Simpulan: Pada kasus ini, diagnosis fasciitis nekrotikan tipe II yang disebabkan oleh Acinetobacter baumanii ditegakkan berdasarkan anamnesis, pemeriksaan fisik, pemeriksaan hematologik, dan kultur pus yang khas.
\end{abstract}

Kata kunci: fasciitis nekrotikan tipe II, skor LRINEC

Fasiitis nekrotikan (FN) atau sering disebut "flesh eating bacteria" adalah nekrosis progresif di lemak sub kutan dan fascia. Penyakit ini termasuk infeksi nekrotikan kulit dan jaringan lunak (skin and soft tissue infections - SSTI). ${ }^{1,2}$ Fasciitis nekrotikan jarang ditemukan. Sekitar 5001500 kasus FN dilaporkan setiap tahun di 
Amerika Serikat. ${ }^{1}$ Di Indonesia data kasus fasciitis nekrotikan belum tersedia.

Fasiitis nekrotikan terbagi dalam beberapa varian. 1) Varian berdasar jenis mikroba: FN tipe I (infeksi polimikrobial), FN tipe II dan gangren streptokokal (infeksi monomikrobial); 2) Varian berdasar struktur ekstrafasia: selulitis nekrotikan sinergisitik (seluruh struktur jaringan lunak terkena, termasuk kulit dan otot), gangren bakterial progresif sinergisitik (selulitis nekrotikan di daerah abdomen, toraks, akibat benang jahit yang tertinggal); 3) Varian berdasar lokasi anatomi (FN servikal dan kraniofasial, gangren Fournier). ${ }^{2}$

Penyebab FN tipe II yang paling sering ialah bakteri group $A \quad \beta$-hemolytic streptococcus (GAS). FN tipe II dapat juga disebabkan oleh infeksi monomikrobial lainnya seperti Methicillin-Resistant Staphylococcus Aureus (MRSA), Vibrio spesies, Klebsiellla spesies, Aeromonas spesies, dan Acinetobacter spesies. Insiden tidak dipengaruhi oleh jenis kelamin, namun diduga berkaitan dengan bertambahnya usia, kondisi imunokompromais termasuk AIDS, diabetes, penyakit jantung kronis, penyakit pembuluh darah perifer, trauma, serta riwayat kecanduan alkohol dan pengguna obat terlarang. ${ }^{1-3}$

Kelainan hematologis dapat digunakan untuk memrediksi terjadinya FN dengan menggunakan sistem skor yaitu Laboratory Risk Indicator for Necrotizing Fasciitis (LRINEC). Pemeriksaan penunjang lain ialah biopsi untuk kultur dan pemeriksaan histopatologik. $^{2}$

Penatalaksanaan FN meliputi pemberian antibiotika sistemik dan debrideman. ${ }^{1,2}$

\section{LAPORAN KASUS}

Seorang laki-laki, 68 tahun, datang ke instalasi gawat darurat RSUP Prof. Dr. R. D. Kandou dengan keluhan bengkak merah kehitaman dan luka di tungkai kiri. Awalnya timbul bercak kemerahan di lutut disertai nyeri 5 hari yang lalu. Tiga hari kemudian timbul lepuh di atas bercak kemerahan yang kemudian pecah dan menjadi luka. Riwayat trauma sebelumnya saat ke kebun. Terdapat demam, serta nyeri dan hangat pada perabaan. Pasien mengobati sendiri luka tersebut dengan betadin, namun tidak membaik. Riwayat penyakit kencing manis, hipertensi, penyakit paru, ginjal, dan hati disangkal. Pasien tidak memiliki riwayat asma bronkial, alergi obat atau makanan, maupun penyakit atopik lainnya. Tidak terdapat keluhan serupa sebelummnya baik pada pasien maupun pada keluarganya. Pasien masih aktif bertani di sawah dan kebun. Pasien sehari-harinya bekerja tanpa memakai sepatu bot sehingga sering timbul luka di kaki.

Pada pemeriksaan fisik didapatkan keadaan umum pasien tampak sakit sedang, kesadaran kompos mentis, tekanan darah $100 / 60 \mathrm{~mm} / \mathrm{Hg}$, nadi 94 kali per menit, pernapasan 22 kali per menit, dan suhu tubuh $38,8^{\circ} \mathrm{C}$. Tinggi badan $158 \mathrm{~cm}$, berat badan $56 \mathrm{~kg}$ dengan kesan gizi cukup. Pemeriksaan torak dan abdomen tidak didapatkan kelainan.

Status dermatologis pada regio genu dan femoralis sinistra didapatkan makula eritem sampai kehitaman, batas difus, disertai erosi, ekskoriasi, edema, nyeri tekan, adanya pus, krusta coklat kehitaman, serta hangat pada perabaan.

Pada pemeriksaan darah rutin didapatkan kadar hemoglobin 10,1 g/dL, leukosit 27.600/ $\mathrm{mm}^{3}$, hitung platelet $248.000 / / \mathrm{mm}^{3}$, natrium $111 \mathrm{mEq} / \mathrm{L}$, kalium 4,6 mEq/L, chlorida $83 \mathrm{mEq} / \mathrm{L}$, gula darah puasa $80 \mathrm{mg} / \mathrm{dL}$, CRP $130 \mathrm{mg} / \mathrm{L}$, kreatinin $0.9 \mathrm{mg} / \mathrm{dL}$, ureum $19 \mathrm{mg} / \mathrm{dL}$, danfungsi hati dalam batas normal. Hasil pemeriksaan urine terdapat leukosit 15-20/lpk dan epitel 3-4/lpk. Hasil X-foto tulang-tulang intak, tak ada osteolitik, serta soft tissue swelling. Hasil kultur pus memperlihatkan adanya Acinetobacter baumanii. Skor LRINEC 6.

Berdasarkan anamnesis serta pemeriksaan fisik dan laboratorium awalnya kasus ini didiagnosis selulitis dengan diagnosis banding erisipelas. Terapi yang diberikan injeksi seftriakson $2 \times 1 \mathrm{~g}$ disertai kompres $\mathrm{NaCl} \quad 0,9 \%$ pada lesi. Setelah terjadi 
jaringan nekrotik yang kemudian menjadi eskar dan berdasarkan hasil kultur pus maka didiagnosis banding dengan fasciitis nekrotikan, selulitis gangrenosa, mionekrosis anaerobik, dan pioderma gangrenosum. Pada perawatan hari ke-8 dilakukan debrideman. Setelah debrideman diagnosis menjadi fasiitis nekrotikan tipe II. Antibiotik diganti dengan klindamisin $3 \times 300 \mathrm{mg}$. Ulkus kemudian dirawat dengan gel yang mengandung madu. Pada hari ke60 ulkus sembuh dengan meninggalkan skar hipertrofik.
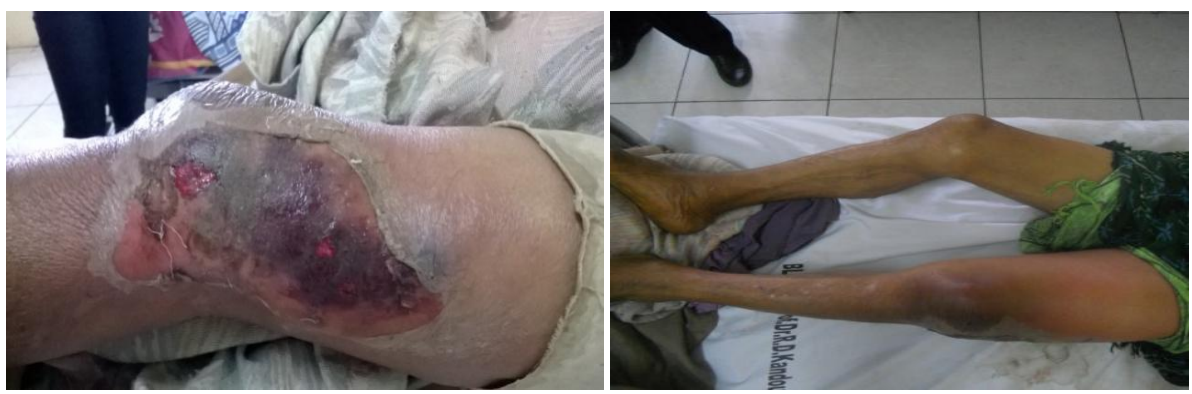

Gambar 1 A dan B. Status dermatologis regio genu dan femoralis sinistra pada tanggal 2 Maret 2014 (hari ke-1). Tampak makula eritem sampai kehitaman, batas difus, disertai erosi, ekskoriasi, edema, nyeri tekan, adanya pus, krusta coklat kehitaman, serta hangat pada perabaan.

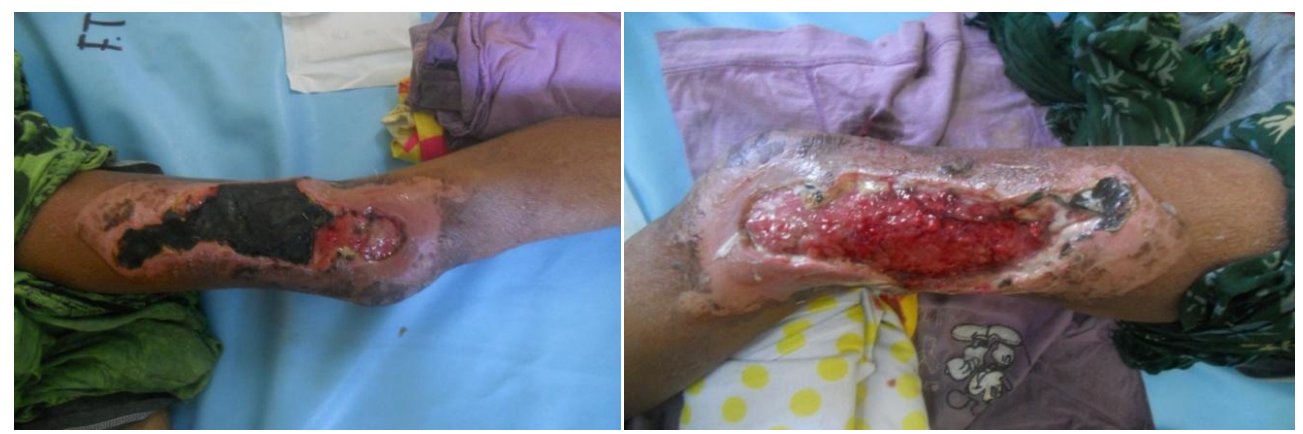

Gambar 2. Status dermatologis tanggal 9 Maret 2014 (hari ke-8). A, Sebelum debridemen. B, Sesudah debridemen.

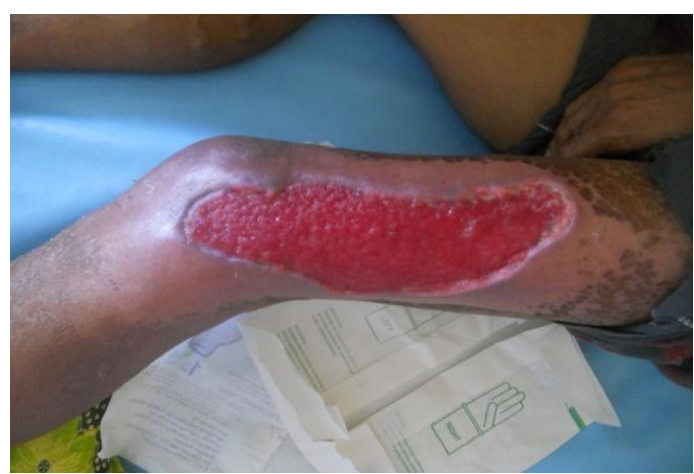

Gambar 3. Status dermatologis pada tanggal 28 Maret 2014 (hari ke-27). Dasar ulkus tampak bersih dan sudah meninggi

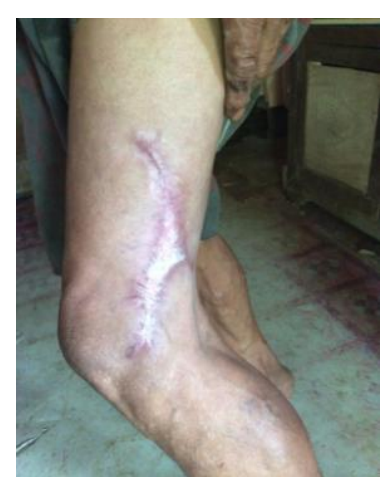

Gambar 4. Status dermatologis pada tanggal 26 Juli 2014 (hari ke-60) dengan skar hipertrofik 


\section{BAHASAN}

Diagnosis kasus ini ditegakkan berdasarkan anamnesis, pemeriksaan fisik, dan laboratorium. Pasien ini seorang lakilaki berusia 68 tahun yang masih aktif bertani di sawah dan kebun. Pasien sehariharinya bekerja tanpa memakai sepatu bot sehingga sering timbul luka di kaki. Lukaluka di kaki ini dicurigai menjadi port d'entrée kuman.

Fasiitis nekrotikan terjadi melalui tiga tahap. Pada tahap pertama timbul gejala menyerupai selulitis yaitu demam tinggi, bengkak, eritema, hangat pada perabaan dan nyeri tekan. Pada tahap kedua terbentuk bula dan edema yang semakin membesar, dan pada tahap ketiga warna kulit menjadi keunguan dan kemudian terjadi gangren kulit (berlangsung dalam 24-48 jam). Pada tahap akhir ini rasa nyeri akan hilang karena terjadi oklusi pada pembuluh darah kecil dan kerusakan sarafsaraf superfisial di jaringan subkutan (berlangsung dalam 4-5 hari).,

Pada kasus ini, pasien mengeluhkan adanya bengkak merah kehitaman dan luka di tungkai kiri. Awalnya timbul bercak kemerahan dan bengkak di lutut yang disertai nyeri. Tiga hari kemudian timbul lepuh di atas bercak kemerahan yang kemudian pecah dan menjadi luka. Lima hari kemudian mulai terbentuk bercak kehitaman dan kemudian terjadi nekrosis. Adanya riwayat trauma di kaki sebelumnya. Terdapat demam, serta nyeri dan teraba hangat pada perabaan. Pasien mengobati sendiri luka tersebut dengan betadin, namun tidak ada perbaikan. Pada pemeriksaan fisik pasien ditemukan makula eritem sampai kehitaman batas difus, hangat pada perabaan disertai erosi dan ekskoriasi. Beberapa hari kemudian terbentuk eskar. Perkembangan penyakit pasien sesuai dengan acuan pustaka dimana awalnya terjadi selulitis sampai akhirnya terjadi gangren kulit.

Pemeriksaan penunjang yang dibutuhkan antara lain pemeriksaan laboratorium, biopsi untuk kultur dan pemeriksaan histopatologik, serta pemeriksaan radiologi
(CT, MRI, ultrasound). Pada pasien ini dilakukan pemeriksaan laboratorium, kultur pus, dan radiologi. Dari hasil laboratorium dapat digunakan suatu sistem skor yaitu Laboratory Risk Indicator for Necrotizing Fasciitis (LRINEC) untuk memrediksi terjadinya FN. Skor 6 memiliki nilai prediksi $92 \%$ sedangkan skor 8 nilai prediksi sangat kuat. Prediksi negatif bila nilai kurang dari $6{ }^{2,5}$ Pada pasien ini didapatkan skor LRINEC 6 (CRP 0, Leukosit 2, hemoglobin 2, sodium 2, kreatinin 0, glukosa 0). Hasil ini sudah dapat menunjukkan kecurigaan untuk terjadinya FN.

Tabel 1. Laboratory Risk Indicator for Necrotizing Fasciitis (LRINEC), ${ }^{2,5}$

\begin{tabular}{lc}
\hline Parameter Laboratorium & Skor \\
\hline Protein C-reaktif $(\mathrm{mg} / \mathrm{L})$ & \\
$\quad<150$ & 0 \\
150 atau lebih & 4 \\
Leukosit $\left(\right.$ per $\left.\mathrm{mm}^{3}\right)$ & \\
$\quad<15$ & 0 \\
$\quad 15-25$ & 1 \\
$\quad>25$ & 2 \\
Hemoglobin $(\mathrm{g} / \mathrm{dL})$ & \\
$\quad>13,5$ & 0 \\
$11-13,5$ & 1 \\
$\quad<11$ & 2 \\
Sodium $(\mathrm{mEq} / \mathrm{L})$ & 0 \\
$\quad>135$ & 2 \\
$\quad<135$ & \\
Kreatinin $(\mathrm{mg} / \mathrm{dL})$ & 0 \\
$\quad<1,6$ & 2 \\
$\quad>1,6$ & \\
Glukosa $(\mathrm{mg} / \mathrm{dL})$ & 0 \\
$\quad<180$ & 1 \\
$\quad>180$ & \\
\hline
\end{tabular}

Hasil kultur pus ialah Acinetobacter baumanii. FN tipe II paling sering disebabkan oleh streptokokus grup $\mathrm{A}^{2}$ Fasciitis nekrotikan tipe II yang disebabkan oleh Acinetobacter baumanii jarang ditemukan. ${ }^{6}$

Hasil pemeriksaan radiologik menunjukkan tulang-tulang intak, tanpa osteolitik, dan adanya soft tissue swelling. Hasil pemeriksaan radiologik tidak signifikan dalam diagnosis dan manajemen 
FN karena hanya menunjukkan adanya gas subkutan yang terlihat pada sebagian kecil kasus dan penebalan jaringan lunak yang mirip dengan selulitis. Beberapa modalitas pencitraan seperti Magnetic Resonance Imaging (MRI), Computed Tomography (CT), dan ultrasound dapat menunjukkan gambaran FN yaitu penebalan fasia dan adanya cairan serta gas pada jaringan yang berdekatan. $^{2,7}$

Baku emas diagnosis $\mathrm{FN}$ ialah eksplorasi secara bedah, palpasi, dan visualisasi langsung fascia yang nekrotik berwarna keabuan tanpa adanya perdarahan. Dengan diseksi tumpul akan tampak foul-smelling discharge dan biasanya didapatkan kurangnya perlekatan fasia dengan jaringan dibawahnya. Selain bedah terbuka, belum ada pemeriksaan yang spesifik untuk menegakkan diagnosis $\mathrm{FN}^{2}{ }^{2}$ Pada pasien ini tidak dilakukan bedah terbuka pada awalnya karena pasien masuk dengan tanda sepsis dan masih didiagnosis sebagai selulitis. Setelah terbentuk eskar maka langsung dilakukan debrideman.

Penatalaksanaan pasien ini ialah pemberian antibiotik sistemik dan debrideman. Antibiotik yang diberikan ialah injeksi seftriakson $2 \times 1 \mathrm{~g}$ (6 hari) kemudian klindamisin 2x300 mg kapsul (14 hari) dan dilanjutkan dengan siprofloksasin $2 \times 500$ mg tablet (6 hari). Debrideman dilakukan pada hari ke-8 setelah masuk rumah sakit. Setelah dilakukan debrideman infeksi tidak meluas dan keadaan umum pasien semakin membaik.

Ulkus paska debrideman pada pasien ini dirawat dengan dressing (balutan luka) gel yang mengandung madu. Pada luka, madu mempunyai efek oklusif dan higroskopik, stimulasi pertumbuhan jaringan dan epitelisasi, antimikroba, debrideman enzimatik, menghilangkan bau luka dan dapat mengaktivasi sistem imun. ${ }^{8,9}$ Pada pasien ini gel dioleskan sebanyak 3 kali per hari sampai luka mulai tertutup. Luka pasien menutup setelah sekitar 2 bulan keluar rumah sakit.

Awalnya kasus ini didiagnosis banding dengan erisipelas. Gejala klinis erisipelas ialah lesi berwarna merah cerah, berbatas tegas, tepi meninggi, dapat disertai edema, vesikel, bula, serta adanya tanda-tanda radang akut. Hasil pemeriksaan fisik menunjukkan gambaran lesi yang berbatas difus sehingga diagnosis erisipelas sudah dapat disingkirkan. Setelah mulai terjadi nekrosis jaringan dan eskar maka dibuat diagnosis banding dengan $\mathrm{FN}$, selulitis gangrenosa, mionekrosis anaerobik, dan pioderma gangrenosum. Selulitis gangrenosa mengenai dermis dan jaringan subkutan, sedangkan mionekrosis mengenai otot. Diagnosis banding selulitis gangrenosa dan mionekrosis disingkirkan karena saat dilakukan debrideman tampak otot yang masih intak. Pioderma gangrenosum dapat disingkirkan karena penyakit secara klinis tidak menyerupai selulitis, berhubungan dengan inflammatory bowel disease, perkembangannya lambat, tepi ulkus berwarna keunguan, diperparah dengan tindakan bedah, serta pemeriksaan darah dan kultur biasanya negatif. ${ }^{10}$

Fasiitis nekrotikan dapat mengancam nyawa. Angka mortalitas berkisar 17-49\%. ${ }^{2}$ Prognosis quo ad vitam dubia ad bonam, quo ad functionam dubia ad bonam, quo ad sanationam dubia ad bonam.

\section{SIMPULAN}

Telah dilaporkan sebuah kasus faciitis nekrotikan tipe II yang disebabkan oleh Acinetobacter baumanii pada seorang lakilaki berusia 68 tahun. Diagnosis ditegakkan berdasarkan anamnesis, pemeriksaan fisik, dan pemeriksaan penunjang. Pemeriksaan penunjang antara lain laboratorium, kultur pus, dan radiologi. Dari hasil laboratorium dapat digunakan sistem skor LRINEC untuk memrediksi terjadinya fasciitis nekrotikan.

Penatalaksanan fasiitis nekrotikan dengan pemberian antibiotik sistemik dan debrideman.

\section{DAFTAR PUSTAKA}

1. Millet CR, Halpern AV, Reboli AC, Heyman WR. Bacterial Diseases. In: Bolognia JL, Jorizzo JL, Schaffer JU, editors. Dermatology (3rd ed.). China: 
Elsevier, 2012; p.1199-1200.

2. Lipworth AD, Saavedra AP, Weinberg AN, Johnson RA. Necrotizing fasciitis, gangrenous cellulitis, and myonecrosis. In: Wolff K, Goldsmith LA, Katz SI, Gilchrest BA, Paller AS, Leffel DJ, editors. Fitzpatrick's Dermatology in General Medicine (8th ed.). New York: McGraw Hill, 2012; p. 2169-77.

3. Stoneback JW, Hak DJ. Diagnosis and management of necrotizing fasciitis. [cited 2015 March 5]. Available from: http://www.healio.com/orthopedics/infec tion/journals/ortho/2011-3-

343/\%7B8b46a436-3fb2-49ef-8c16$64877 \mathrm{c} 99 \mathrm{e} 4 \mathrm{c} 8 \% 7 \mathrm{D} /$ diagnosis-andmanagement-of-necrotizing-fasciitis.

4. James WD, Berger TG, Elston DM. Bacterial infections. In: James WD, Berger TG, Elston DM, editors. Andrew's Disease of the Skin (10th ed.). Philadelphia: Saunders Elsevier, 2006; p. 261-2.

5. Semon G, Liu $X$. Necrotizing soft tissue infections. Cheatham ML, editor. [cited 2014 Dec 12]. Available from: http://www.surgicalcriticalcare.net/Guid elines/NSTI\%202014.pdf

6. Charnot-Katsikas A, Dorafshar AH, Aycock JK, David MZ, Weber SG,
Frank KM. Two Cases of necrotizing fasciitis due to Acinetobacter baumannii. [cited 2015 Jan 6]. Available from: http://www.ncbi.nlm.nih.gov/pmc/article s/PMC2620842.

7. Fugitt JB, Puckett ML, Quigley MM, Kerr SM. Fasciitis necrotizing. [cited 2015 March 5]. Available from: http://www.pubs.rsna.org/doi/full/10.114 8/rg.245035169.

8. O'Toole EA, Mellerio JE. Wound healing. In: Burns $\mathrm{T}$, Breathnach $\mathrm{S}$, Cox $\mathrm{N}$, Griffiths C, editors. Rook's Textbook of Dermatology (8th ed.). Singapore: Willey-Blackwell, 2010; p.1417-21.

9. Shai A, Maibach HI. Alternative topical preparations. In: Shai A, Maibach HI,editors. Wound Healing and Ulcers of the Skin: Diagnosing and TherapyThe Practical Approach. Berlin: Springer-Verlag Berlin Heidelberg, 2005; p. 212-4.

10. Tilkorn DJ, Citak M, Fehmer T. Comparison of pathology and clinical features of pyoderma gangrenosum and necrotizing fasciitis. [cited 2014 Nov 5]. Available from: http://www.ncbi.nlm.nih.gov/pmc/article s/PMC3097992/table/T2/. 